\title{
PEMERTAHANAN BAHASA ARAB-NUSANTARA: \\ BAGAIMANA EKOLOGI MEMAINKAN PERANNYA ${ }^{1}$
}

\author{
Eric Kunto Aribowo \\ Universitas Widya Dharma Klaten \\ erickunto@unwidha.ac.id
}

\begin{abstract}
In the Middle East and North Africa (Arabian Peninsula), Arabic used as a means of daily communication can be classified into: fuṣhā (High variety) and 'ammiyyah (Low variety). Thousands miles from her origin, and after inhabiting the new area after hundreds years, Arabic evolved and developed in such a way, so as to form a new variation, such as Arabic which is still used by the "muwallad" (community of Arab descents) in Nusantara. However, the forms are maintained to this day by the community is not something that happens for no reason. This paper offers a number of non-linguistic parameters (variables) relating to ecology (language environment) which supports Arabic language maintenance -which has evolved; mixed with local languages- are still constantly used by the community of Arab descents to the present.
\end{abstract}

Keywords: ecology of language, Arab-Nusantara, language maintenance, Arabs descents, muwallad

\section{Pendahuluan}

Bahasa Arab merupakan bahasa resmi di dua puluh negara di Timur Tengah dan Afrika Utara: dan satu negara, Palestina, di mana bahasa Ibrani merupakan bahasa resmi pertama dan bahasa Arab sebagai bahasa resmi kedua. Kedua puluh negara tersebut adalah Maroko, Aljazair, Mauritania, Tunisia, Libya, Sudan, Mesir, Djibouti, Somalia, Arab Saudi, Kuwait, Bahrain, Qatar, Uni Emirat Arab, Oman, Yaman, Yordania, Suriah, Irak, dan Lebanon. Bahasa Arab juga dituturkan oleh penduduk Palestina yang tinggal di Tepi Barat dan Gaza (Holes, 2004: 1).

Bahasa ini termasuk dalam bahasa klasik yang paling luas penggunaannya di dunia -daripada bahasa-bahasa klasik lainnya, seperti bahasa Latin, bahasa Sansekerta, atau bahasa Ibrani. Hal ini disebabkan karena bahasa ini merupakan bahasa Alquran yang dibaca oleh jutaan kaum muslimin di segala penjuru dunia, yang kemudian digunakan dalam penulisan maupun pembahasan masalah-masalah yang masih terkait dengan agama. Selain itu, kalam kancah internasional, sejak 1 Januari 1971 bahasa Arab ditetapkan sebagai bahasa internasional di PBB setelah bahasa Inggris, Perancis, Spanyol, Rusia, dan Mandarin.

Menurut karakteristiknya, bahasa Arab digolongkan ke dalam rumpun bahasa Semit -istilah yang digunakan untuk menunjuk sekelompok bahasa, beberapa bahasa telah lama mati (punah), beberapa masih hidup, dan ada beberapa bahasa yang saat ini memiliki status marginal sebagai bahasa liturgi (keagamaan). Pengelompokan bahasa ini didasarkan atas kesamaan stuktur pada tataran fonologi, morfologi, dan kosa kata dasar yang sama-sama berasal dari Proto-Semit. Bahasa purba ini menurut asal-

\footnotetext{
${ }^{1}$ Aribowo, E. K. (2014) "Pemertahanan Bahasa Arab-Nusantara: Bagaimana Ekologi Memainkan Perannya," in The Arabic Culture Identity: Facts and Challenges. Yogyakarta: IDEA Press, hal. 131-147.

Makalah ini dipersembahkan kepada segenap staf pengajar Sastra Arab UGM sebagai pendidik sekaligus inspirator penulis, terutama Drs. Mudjeri yang belum lama ini berpulang
} 
usul geografisnya -yang ditelusuri melalui dokumen-dokumen tertulis- merupakan bahasa ibu di daerah Timur Dekat ${ }^{2}$ sekitar tahun 2500 SM (Holes, 2004: 10). Ini berarti bahwa bahasa Arab yang saat ini dituturkan di kawasan Afrika Utara, khususnya Mesir, bukan merupakan bahasa asli daerah tersebut. Keadaan ini terjadi karena faktor penaklukan yang dilakukan oleh tentara-tentara Arab muslim. Daerah tersebut mengalami proses islamisasi dan arabisasi (menjadi Arab; masyarakat yang berbahasa Arab) secara total (dengan dibuktikan punahnya bahasa Mesir) yang terjadi pada awal Islam sekitar awal abad ke- $8^{3}$. Anehnya, Iran tidak mengalami hal serupa. Meskipun terdapat beberapa daerah di mana bahasa Arab masih dituturkan, tetapi bahasa Persi masih menjadi bahasa resmi negara Iran hingga saat ini.

Jauh dari negeri asalnya, bahasa Arab ternyata mewarnai keberagaman bahasa di Nusantara sebagaimana ditulis oleh Fauziah (2007), Fuad (2008), Sholihatin (2008), Husin (2009), dan Azzuhri (2011; 2013). Uniknya adalah bahasa Arab yang digunakan oleh masyarakat keturunan Arab bukan merupakan bahasa Arab yang sama sebagaimana bahasa Arab yang dituturkan di tempat asalnya. Bahasa Arab ini telah mengalami evolusi dan perkembangan berupa modifikasi-modifikasi, yang tentu saja dipengaruhi oleh lingkungan sekitar (khususnya bahasa-bahasa lokal/daerah).

Salah satu varian bahasa Arab yang ada di Nusantara berada di Martapura, Banjarmasin. Martapura yang selain dikenal dengan julukan "Kota Intan" juga dikenal sebagai "Kota Santri". Ini dikarenakan banyak didapati pesantren, madrasah, dan majlis taklim informal lainnya, yang tidak lain merupakan peran serta masyarakat keturunan Arab. Berikut contoh ungkapan 'tidak ada gunanya' yang dituturkan oleh masyarakat keturunan Arab.

$\begin{array}{llll}m a & p i & \text { pedah } & \text { Arab-Banjar } \\ \text { neg. } & \text { lok. } & \text { guna } & \\ \text { bandingkan dengan } & \\ m \bar{a} & \text { fihi } & \text { faydah } & \text { Arab Standar } \\ \text { neg. } & \text { lok.pro } & \text { guna } & \end{array}$

Sumber: (Husin, 2009: 5)

Dapat diamati bahwa terdapat beberapa modifikasi yang terjadi pada bahasa Arab-Banjar. Modifikasi bunyi [f] menjadi [p] pada bahasa Arab-Banjar tampak pada kata /faydah/ > pedah/ dan / fi / > /pi/. Hal ini diasumsikan karena bahasa Banjar tidak memiliki fonem /f/. Oleh karena itu, realisasi bunyi [f] digantikan dengan fonem $/ \mathrm{p} / 4$. Perubahan pada kata $/$ faydah $/>/$ pedah/ juga terjadi gejala yang disebut dengan monoftongisasi, yakni perubahan dua bunyi vokal atau vokal rangkap (diftong) menjadi vokal tunggal (monoftong). Dengan kata lain, terdapat perubahan bunyi diftong [ay] menjadi vokal tunggal [e]. Selain itu, terjadi pula pemendekan dari vokal panjang /ā/ menjadi vokal pendek /a/. Ini merupakan hal

\footnotetext{
${ }^{2}$ istilah yang sering digunakan oleh arkeolog dan sejarawan untuk merujuk kepada kawasan Levant atau Syam (sekarang Israel, Jalur Gaza, Lebanon, Suriah, Tepi Barat, dan Yordania), Anatolia (sekarang Turki), Mesopotamia (Irak dan Suriah timur), dan Iran. Istilah alternatif yang jarang dipakai adalah "Asia Barat Daya".

${ }^{3}$ sekitar 80.000 tentara Arab berpusat di Fușțāt, yang saat ini dikenal dengan nama Kairo dan Alexandria (Holes, 2004: 30).

${ }^{4}$ dari penelurusan yang dilakukan, belum ditemukan referensi yang membahasa mengenai fonologi bahasa Banjar. Asumsi ini disimpulkan dari mencermati leksikon yang terdapat dalam "Kumpulan Bahasa Banjar disertai terjemahan semampunya ke Bahasa Indonesia Edisi I" (2010) yang diunduh dari http://www.bahasabanjar.net.
} 
yang lazim karena bahasa Banjar (dan mayoritas bahasa-bahasa di Nusantara lainnya) tidak mengenal adanya vokal panjang.

Contoh lain adalah munculnya apa yang saya sebut sebagai akulturasi leksikal. Maksudnya adalah munculnya sebuah kata baru yang merupakan perpaduan dari dua morfem yang berasal dari bahasa yang berbeda. Dalam hal ini, ditemukan bahwa morfem dasar berasal dari bahasa Arab, sedangkan morfem bebas berasal dari bahasa lokal sebagaimana dapat dilihat pada contoh berikut.

/al-fatāt taštarī yu?kulan/

'Gadis itu membeli makanan' (Fuad, 2008: 79)

Kata /yu?kulan/ berasal dari verba /yu?kul/, yang merupakan variasi dialek dari verba /ya?kulu/. Adapun akhiran \{-an\}, bukan merupakan unsur linguistik dari bahasa Arab karena [an] bukan merupakan afiks, melainkan bunyi nunasi atau tanwin yang berfungsi sebagai penanda indefinit dan tanda kasus akusatif pada nomina yang berfungsi sebagai objek. Akhiran $\{-a n\}$ merupakan input dari sistem kebahasaan yang lazim ditemui di bahasa-bahasa Austronesia. Kata /sugulan/ 'semua pada bekerja' (Husin, 2009) dan /zuwatan/ 'pernikahan' (Fauziah, 2007) merupakan contoh lain dari bentuk akulturasi leksikal5.

Hal ini mengindikasikan bahwa bahasa Arab (melalui penuturnya) masih menunjukkan eksistensinya di Nusantara. Tentunya, lingkungan sekitar turut memberikan sumbangsih terhadap kelangsungan hidup bahasa Arab di antara 420-an bahasa yang hidup di Nusantara. Adapun beberapa perubahan kebahasaan yang terjadi merupakan bukti bahwa adanya adaptasi terhadap lingkungan sekitar (khususnya adalah bahasa-bahasa daerah).

Tidak dapat dipungkiri bahwa masuknya bahasa Arab ke Nusantara merupakan imbas dari masuknya Islam. Yang lebih menarik adalah dengan pintu masuk berupa penyiaran agam Islam ke Nusantara -yang telah disepakati bersama oleh para sejarawan terjadi karena jalur perdagangan maritimbahasa Arab (khususnya variasinya) lebih dapat diamati wujudnya hingga saat ini hanya di daerah-daerah di Nusantara. Mengapa kehadirannya tidak begitu tampak di Malaka (Singapura), India, bahkan Tiongkok, yang sebenarnya juga merupakan jalur perdagangan di kala itu? Ini berarti, latar historis tidak mampu dijadikan pondasi sebagai jawaban dari pertanyaan tersebut. Untuk itu, landasan ekologis dipilih untuk mencoba menjelaskan bahasa dalam rangka mempertahankan kehidupannya.

\section{Ekologi Bahasa}

Istilah ekologi bahasa (language ecology) diperkenalkan pertama kali oleh Haugen (1972) dalam bukunya yang berjudul The Ecology of Language. Menurut Haugen, ekologi bahasa dapat didefinisikan sebagai "interactions between any given language and its language ecology may be defined as the study of environment". Istilah "ekologi bahasa", seperti halnya "rumpun bahasa", merupakan sebuah metafora yang berasal dari studi tentang makhluk hidup. Teori ini memiliki pandangan bahwa seseorang dapat melakukan pengkajian mengenai hubungan timbal balik antara bahasa (sebagai organisme) dengan lingkungan mereka, di mana bahasa dapat dianalogikan sebagai sebagai entitas -sesuatu yang memiliki keberadaan yang unik dan berbeda-, bahwa mereka dapat berada dalam ruang dan waktu tertentu, serta ekologi bahasa setidaknya merupakan bagian berbeda dari penuturnya (Mühlhäusler, 1996: 2-3).

\footnotetext{
${ }^{5}$ tulisan lebih lanjut mengenai perubahan yang terjadi pada bahasa Arab-Nusantara dapat dilihat pada Aribowo (2014) "Bahasa Hibrida: Bukti Harmoni Akulturasi Budaya Arab-Nusantara".
} 
Ekologi bahasa juga didefinisikan sebagai sebuah studi tentang interaksi antara bahasa dengan lingkungannya (ecology of language) (Kridalaksana 2008: 39). Lingkungan bahasa dalam pengertian ini menyangkut pemakaian bahasa sebagai sebuah kode (tanda) yang digunakan sebagai alat komunikasi oleh sebuah masyarakat. Dengan demikian, bahasa diartikan sebagai kosa kata referensial dari sebuah masyarakat dan gramatika (tata bahasa)-nya serta lingkungan diartikan sebagai masyarakat sebagai pemakai bahasa tersebut yang meliputi lingkungan alam dan lingkungan sosial.

Bahasa hanya bisa eksis bila ada penuturnya dan digunakan sebagai alat komunikasi. Bahasa itu berada dalam diri (pikiran/jiwa) penutur dan berfungsi sebagai alat interaksi sosial (berkomunikasi) serta memang bahasa dibentuk untuk berkomunikasi dan merupakan hasil kehidupan bermasyarakat.

Berkaitan dengan pengaruh ekologi terhadap bahasa telah dikemukakan sebelumnya oleh Mühlhäusler (2006) yang berfokus pada bahasa-bahasa di kawasan Pasifik (Australia dan Melanesia), Ansaldo (2009) pada bahasa-bahasa di Asia, dan al-Syarkhawi (2009) pada bahasa Arab.

Mühlhäusler (2006) menyebutkan bahwa imperealisme berupa perdagangan dan eksploitasi ekonomi yang dilakukan oleh bangsa Inggris menyebabkan kontak antara bangsa kolonial dengan penduduk pribumi. Secara simultan kontak yang terjadi jelang tahun 188o-1975 memunculkan bahasabahasa Inggris pijin di Kaledonia Baru, Nugini, Papua, Samoa, dan Queensland.

Ansaldo (2009: 18-51) merumuskan beberapa poin penting yang mempengaruhi munculnya bahasa Melayu Baba dan Bazar, Melayu Cocos, dan Pijin China Pesisir: (a) angin Muson Asia -Muson Barat dan Muson Timur- yang berhembus sepanjang China Selatan, pesisir Asia Tenggara, dan bagian timur Hindia Belanda; (b) perdagangan China-Jawa yang diselenggarakan oleh kesultanan Muslim, India, China, dan kerajaan-kerajaan dagang Jawa; (c) munculnya kota-kota pelabuhan (yang sebagian besar ada di utara pulau Jawa) yang merupakan imbas dari kerjaan Funan, Champa, dan Sriwijaya; (d) tenaga kerja di awal Asia Tenggara, khususnya saat tanam paksa; dan (e) imbas masuknya kaum Barat, seperti Portugis, Belanda, dan Inggris.

Jika ditilik dari sudut pandang sejarah, bahasa Arab di Mesir -dan beberapa negara di Afrika Utara lainnya- bukan merupakan bahasa asli Mesir. Sebagaimana diungkap oleh al-Sharkawi (2009) bahwa proses arabisasi yang terjadi di kawasan Timur Tengah disebabkan karena datangnya tentara-tentara muslim saat penaklukan Islam yang secara serta merta diikuti oleh urbanisasi dan migrasi bangsa Arab ke kawasan Mesir dan sekitarnya. Dengan demikian, bahasa Yunani dan Latin yang digunakan pada masa Romawi dalam kegiatan administrasi digantikan dengan bahasa Arab.

\section{Diskusi dan Pembahasan}

Pada kesempatan berikut, saya paparkan beberapa temuan mengenai kondisi lingkungan yang menyebabkan keberlangsungan serta perkembangan bahasa Arab di Nusantara mendapatkan dukungan dari ekologi bahasa di sekitarnya hingga saat ini. Setidaknya terdapat empat elemen yang mempengaruhi keberlangsungan bahasa Arab di Nusantara. Secara lebih detil akan dijelaskan sebagai berikut.

\subsection{Kedatangan yang bergelombang}

Menurut Bahafdullah (2010: 167-171) periode migrasi bangsa Arab ke Nusantara dalam dibagi ke dalam empat tahap. Ini berarti bahwa sebenarnya kedatangan orang Arab ke Indonesia sudah berlangsung

\footnotetext{
${ }^{6}$ bahasa aslinya adalah bahasa Mesir (Kuno) yang ditulis dalam huruf Hieroglif.
} 
sejak lama. Mereka datang sebagai pelaut, pedagang keliling, saudagar kain, pengusaha rempah-rempah, juru dakwah, dan terkadang kesemua profesi itu merupakan kegiatan yang mereka lakukan.

Gelombang pertama dimulai sejak abad ke-12 yakni sejak kedatangan ulama Ba'alwiy dari marga Syihāb ke Siak ${ }^{7}$ yang kemudian menjadi sultan di sana. Kehadiran mereka di Nusantara diterima dengan tangan terbuka, bahkan mendapat tempat yang khusus dalam masyarakat, seperti yang ditulis oleh van den $\operatorname{Berg}(2010)^{8}$.

Pada abad ke-15, merupakan gelombang kedua, waktu berakhirnya kejayaan Kerajaan Majapahit, di Jawa sudah ada penduduk bangsa Arab atau keturunannya. Orang-orang Arab pada masa itu sudah berbaur dengan penduduk setempat, bahkan sebagian di antaranya banyak menduduki jabatan tinggi di kerajaan.

Kalau pada gelombang kedatangan pertama dan kedua mayoritas golongan Habāib atau Sayyid, yang misi utamanya dakwah menyebarluaskan agama Islam, maka kedatangan pada gelombang ketiga, mayoritas non-Habāib yang disebut Ghabīli atau Qabāil ${ }^{\beta}$ yang lebih banyak bertujuan sosial ekonomi di samping agama. Pada masa Hindia Belanda, pendatang Arab tercatat sebagai etnis migran kedua setelah etnis Tionghoa. Kedatangan orang-orang Arab Hadramaut ke Indonesia pada gelombang ini pada dasarnya berorientasi untuk mencari nafkah. Fachruddin (2005: 131) menyebutkan bahwa mereka menjadi pedagang perantara, pedagang kecil, pemilik toko, dan menyediakan barang dan jasa yang tidak dilakukan pendatang dari Eropa, juga melakukan kegiatan meminjamkan uang.

Gelombang keempat ditandai dengan peperangan antara kesultanan al-Katsiri dan al-Quayti yang berlarut-larut. Keadaan ini menyebabkan jumlah Ḥaḍamiy yang meninggalkan negerinya meningkat tajam, seperti yang dicatat Mobini-Kesheh (1996: 238) bahwa pada tahun 1900 jumlahnya mencapai 27.399 dan tahun 1920 menjadi 44.902. Sebagaimana dipaparkan Bahafdullah (2010: 171) bahwa pada tahun 1930 dan tahun-tahun berikutnya, akibat kemelut politik dan keamanan yang semakin ruwet, peperangan yang tidak kunjung usai menyebabkan kedatangan Ḥaḍramiy semakin meningkat. Gejolak ini telah menyebabkan 90.00o dari 256.00o rakyat Ḥaḍamawt hijrah ke berbagai negeri di dunia Arab, Afrika, Amerika, India, dan ke Asia Tenggara yang kebanyakan memilih Indonesia. Menjelang kedatangan tentara Jepang di tahun 1942, orang Ḥaḍramawt diperkirakan sudah berjumlah 80.00o orang.

Dari hal tersebut di atas, didapati bahwa migrasi bangsa Arab dalam beberapa periodik menandakan: (1) datangnya migran Arab yang bertahap dan berkesinambungan berdampak pada semakin bertambahnya komunitas Arab. Komunitas ini kemudian membentuk organisasi Al-Irsyad ${ }^{10}$ merupakan agen perubahan sosial dari sejak didirikannya hingga saat ini; (2) banyak dijumpai komunitas Arab di kota-

\footnotetext{
${ }^{7}$ Kesultanan Siak Sri Inderapura adalah sebuah kerajaan Melayu Islam yang pernah berdiri di Kabupaten Siak, Provinsi Riau.

${ }^{8}$ Menurut pendapat para ahli sejarah, sebagaimana dikemukakan van den Berg (2010) merupakan gambaran masa kehadiran Walisanga di pulau Jawa, yang merupakan kedatangan orang Ḥaḍramawt gelombang pertama.

${ }^{9}$ Stratifikasi dan struktur sosial masyarakat Arab di Nusantara pada mulanya masih mengacu kepada asas garis keturunan yang ada di tanah asalnya (Haḍramawt atau Yaman). Mereka terbagi-bagi dalam berbagai golongan atau kasta. Golongan pertama adalah Sada yang dikenal sebagai golongan agamawan atau Sayyid. Panggilan mereka biasanya adalah Habib. Dalam masyarakat Arab mereka dikenal sebagai golongan 'Alawiy. Golongan kedua, Qabäil yang dikenal sebagai golongan militer. Ketiga golongan Masyäikh, yakni golongan intelektual. Keempat adalah golongan Dafã yang dikenal sebagai pedagang dan petani (van den Berg 2010: 33).

${ }^{10}$ Untuk kalangan orang Arab yang non-Sayyid, nama Al-Irsyād adalah nama yang dijunjung tinggi dan dihormati. Dengan kata lain Al-Irsyād telah mendarah daging pada anggota Al-Irsyād begitu juga dialirkan kepada anak-anaknya turun-temurun, seakan-akan Al-Irsyād adalah rumah bersama warisan orang tuanya yang perlu dijaga dan dikembangkan.
} 
kota yang dulunya merupakan kota pelabuhan di era Sriwijaya dan Majapahit, seperti: Palembang, Tuban, Gresik, Surabaya, Batavia, Cirebon; dan (3) Nusantara tidak lagi dianggap sebagai negeri asing, melainkan telah dianggap sebagai rumah kedua oleh para migran. Dengan demikian, jelaslah bahwa Nusantara bagi para pendatang Arab merupakan tempat yang cocok dan nyaman sebagai daerah tujuan kedatangan dalam rangka migrasi yang selanjutnya didiami untuk melanjutkan hidup.

\subsection{Pemukiman yang terkonsentrasi}

Para perantau atau imigran Arab yang berangkat dari tanah airnya dengan kapal layar biasanya berangkat dari pelabuhan Mukalla atau asy-Syihr. Setelah singgah di pelabuhan Oman, Bombai, Srilanka untuk mengisi air, menambah perbekalan, memuat penumpang dan barang, mereka kemudian singgah di Aceh. Dari sini biasanya para imigran ini menuju Palembang atau Pontianak karena di kedua kota ini terdapat banyak kenalan atau kerabat mereka yang sudah hidup mapan. Bahkan, biasanya para perantau Arab akan singgah beberapa hari sebelum melanjutkan tujuannya ke kota lain. Setalah itu, mereka kemudian menyebar ke kota-kota pelabuhan lain, seperti Batavia, Tuban, Gresik, Surabaya, dan Banjarmasin.

Menurut Bahafdullah (2010: 172), sebelum diberlakukannya peraturan pemukiman (Wijken Stelsel) di awal abad ke-18, kaum muhajirin (pendatang) ini ditempatkan di pemukiman yang sudah ditentukan Belanda. Di Batavia mereka ditempatkan di daerah pantai yang berawa-rawa dengan lingkungan yang tidak sehat seperti di daerah pasar ikan dan pekojan bersama-sama dengan etnis Benggali (India) yang sudah terlebih dahulu tinggal di sana.

Pada tahun 1860—1920, pemerintahan kolonial Belanda mengeluarkan peraturan yang mengatur dan menggolongkan masyarakat Arab dan keturunannya di Nusantara ke dalam bagian Timur Asing (Vreemde Oosterlingen). Kemudian mereka diharuskan tinggal di tempat tertentu yang sudah ditetapkan oleh pemerintah Belanda.

Dalam wilayah tempat tinggalnya itu, mereka dipimpin oleh seorang ketua himpunan yang jabatannya tergantung pada jumlah orang-orang Arab yang dipimpinnya dan diangkat oleh pemerintah Hindia Belanda. Jika jumlah yang dipimpin lebih dari 6 oo orang, maka nama ketua himpunannya adalah Kapten Arab. Jika jumlahnya 30o-6oo orang nama pimpinannya adalah Letnan Arab. Dan jika kurang dari 300 orang nama pimpinannya Ketua. Diberlakukannya sistem ini dengan tujuan untuk memudahkan pemerintah Hindia Belanda dalam memantau aktivitas ekonomi keturunan Arab dengan bekerja sama dengan orang-orang Arab yang diangkatnya (Safira dan Ali Haidar, 2014: 240).

Setelah Wijken Stelsel dicabut pada akhir abad ke-19, mereka mulai mencari pemukiman baru yang lebih sehat seperti Batavia di daerah Krukut, Tanah Abang, Meester Cornelis (Jati Negara), dan Kwitang. Mereka hidup mengelompok membentuk "koloni" yang sangat sejalan dengan tujuan penjajah Belanda yaitu untuk memisahkan mereka dengan penduduk pribumi. Pemukiman mereka yang mengelompok itu ditopang oleh Indische Staat Regeling ${ }^{11}$ yang membagi penduduk Hindia Belanda menjadi tiga golongan, yaitu European (golongan Eropa), Vreemde Oosterlingen ${ }^{12}$ (Arab, India, dan China), dan pribumi atau Inlanders (Bahafdullah, 2010: 172).

Menurut L.C.W. van den Berg (2010: 96—99), koloni ${ }^{13}$ yang sudah terbentuk menjelang abad ke-19 adalah: Batavia, Meester Cornelis (Jati Negara), Bandung, Cirebon, Indramayu, Purwakarta, Tegal,

\footnotetext{
${ }^{\text {11 }}$ Peraturan kependudukan kolonial Belanda

${ }^{12}$ yang secara harfiah berarti orang-orang dari negara-negara Timur yang tidak dikenal (asing).

${ }^{13}$ yang kemudian dikenal dengan sebutan Kampung Arab (Arabisch Kamp).
} 
Pekalongan, Semarang, Jogjakarta, Surakarta, Gresik, Surabaya, Malang, Pasuruan, Besuki, Bangli, Jember, Bondowoso, Probolinggo dan Lumajang, Banyuwangi, Sumenep, Pamekasan, Bangkalan, Palembang, Deli Serdang, Jambi, Aceh, Padang, Pontianak, Banjarmasin, Manado, Gorontalo, Makassar, Donggala, Ampenan, Bima, Ambon, Banda, Ternate, Kupang, Waingapu-Sumba, Sumba, Sumbawa Besar, Pabean, Kemukus, Singaraja, dan Keling, Denpasar, Ende-Flores, Taliwang-Sumbawa. Bahkan, koloni-koloni Arab tersebut masih ada hingga sekarang (amati tabel $\mathbf{1}$ berikut).

Tabel 1. Jumlah Keturunan Arab di tiga wilayah di Nusantara ${ }^{14}$

\begin{tabular}{lrlrlr}
\hline \hline \multicolumn{2}{c}{ Pamekasan, Madura } & \multicolumn{2}{c}{ Pasarkliwon, Surakarta } & \multicolumn{2}{c}{ Pekalongan } \\
\hline \hline Kelurahan & Jumlah & Kelurahan & Jumlah & Kelurahan & Jumlah \\
\hline Jungcangcang & 4.315 & Joyosuran & 409 & Noyontaan & 2.000 \\
Perteker & 2.578 & Semanggi & 13.681 & Klego & 1.418 \\
Gladak Anyar & 2.046 & Kedunglumbu & 672 & \\
Bugih & 1.078 & Kauman & 46 & \\
Nylabuh Laok & 205 & & & & \\
\hline Total & 10.231 & & 14.808 & 3.148 \\
\hline \hline
\end{tabular}

Faktor demografis akan memerankan andil dalam pemertahanan bahasa ketika: (1) suatu komunitas mempunyai jumlah yang banyak untuk membentuk suatu masyarakat tutur; (2) pola pemukiman yang mengelompok dan terpisah dari kelompok mayoritas atau dapat dikatakan mengisolir, sehingga mereka dapat dengan leluasa menggunakan bahasanya.

Dari data pada tabel 1. tersebut menunjukkan jumlah yang cukup besar untuk membentuk sebuah komunitas bahasa. Terlebih ketika menilik pola pemukiman masyarakatnya yang cenderung untuk mengelompok. Dengan jumlah yang cukup besar sebagai sebuah komunitas penutur bahasa dan didukung pula dengan pola pemukiman yang cenderung terkonsentrasi pada wilayah tertentu menjadikan masyarakat keturunan Arab dapat leluasa untuk menggunakan bahasa Arab dengan sesama keturunan Arab.

Lebih lagi, keturunan Arab di Nusantara pada umumnya memiliki solidaritas individu yang terbentuk berdasarkan berbagai kesamaan ikatan, misalnya negeri, agama, bahasa, dan keturunan. Dalam kesehariannya, masyarakat keturunan Arab terlihat sangatlah rukun satu sama lain. Hubungan keluarga terlihat sangat erat, saling membantu, dan saling mengunjungi. Dengan demikian, interaksi yang dilakukan terjadi dilakukan secara intensif dan frekuensi yang tinggi.

\subsection{Perkawinan endogami}

Bentuk perkawinan yang masih dilaksanakan oleh masyarakat keturunan Arab adalah bentuk perkawinan endogami (Sholihatin, 2008; Rizkiati, 2012; dan Kinasih, 2013). Perkawinan endogami merupakan suatu bentuk perkawinan yang berlaku dalam masyarakat yang hanya memperbolehkan kepada anggota masyarakat untuk kawin atau menikah dengan anggota lain dari golongan sendiri. Lebih lanjut lagi, perkawinan endogami ini adalah perkawinan antar kerabat atau perkawinan yang dilakukan antar sepupu (yang masih memiliki satu keturunan), baik dari pihak ayah sesaudara (patrilineal) atau dari ibu sesaudara (matrilineal). Kaum kerabat boleh menikah dengan saudara sepupunya karena mereka yang

\footnotetext{
${ }^{14}$ Untuk data Madura merupakan data tahun 2007 yang diambil dari Fuad (2008: 39); untuk Surakarta data tahun 2013 dari Monografi Kecamatan Pasarkliwon; untuk Pekalongan, data kelurahan Noyontaan tahun 2008 Sholihatin (2008: 70) dan data kelurahan Klego tahun 2010 dari Azzuhri (2011: 39).
} 
terdekat dengan garis utama keturunan dipandang sebagai pengemban tradisi kaum kerabat, perhatian yang besar dicurahkan terhadap silsilah atau genealogis. Hal ini berarti bahwa perkawinan yang dilakukan oleh mempelai harus berasal dari lingkungan kerabat dekat dan larangan untuk melakukan perkawinan dengan pihak dari luar suku atau yang bukan keturunan Arab. Artinya, mereka cenderung hanya kawin dengan sesama anggota etnis Arab ${ }^{15}$.

Selain itu, masyarakat keturunan Arab juga menganut sistem patrineal. Oleh karena itu, masyarakat keturunan Arab perempuan harus menikah dengan masyarakat keturunan Arab laki-laki, sedangkan masyarakat keturunan Arab laki-laki boleh tidak menikah dengan masyarakat keturunan Arab perempuan. Hal ini disebabkan karena bagi kalangan masyarakat keturunan Arab, garis keturunan berada di pihak ayah (laki-laki).

Sebagai contoh adalah apa yang terjadi pada komunitas Arab di daerah Pekalongan (Kinasih, 2013). Kekerabatan golongan sayyid bersifat patrilineal, di mana seorang anak mengikuti garis keturunan ayahnya dan mengenal endogami yang ketat, sehingga hanya laki-laki yang diizinkan untuk menikah ke luar kelompoknya untuk menjaga garis keturunan dengan Nabi Muhammad SAW. Syariffah ${ }^{16}$ haruslah menikah dengan pasangan yang sekufu atau sebanding/sederajat, artinya jodoh syarîfah juga haruslah dari sesama keturunan Nabi (Kinasih, 2013: 43-44). Konsekuensinya, sebagaimana dipaparkan oleh Sholihatin (2008: 96) bahwa anak-anak hasil pernikahan antara masyarakat keturunan Arab perempuan dan laki-laki non-Arab tidak berhak menyandang nama fam (marga/klan Arab) ${ }^{17}$.

Dari penelusuran yang dilakukan oleh Jacobsen (2009) mengenai pola perkawinan masyarakat Arab Hạạramiy di antara tahun 1999-200o di Surabaya, Singaraja, Denpasar, Klungkung, Ampenan, dan Sumbawa Besar didapati data berikut.

Tabel 2. Jumlah Perkawinan Masyarakat Keturunan Arab

\begin{tabular}{lcc} 
& Jumlah & $\%$ \\
\hline \hline Total perkawinan & $\mathbf{1 2 0}$ & $\mathbf{1 0 0}$ \\
\hline \hline Perkawinan Ḥaḍramiy-Hadramiy, dalam strata sosial yang sama & 89 & 74 \\
Perkawinan Ḥaḍamiy-Hadramiy, dalam strata sosial yang berbeda & 3 & 3 \\
Perkawinan dengan muslim non-Haḍramiy lokal & 24 & 20 \\
Perkawinan dengan muslim dari grup imigran lain & 4 & 3 \\
\hline \hline
\end{tabular}

Sumber: Jacobsen (2009: 69)

\footnotetext{
${ }^{15}$ Adanya perkawinan silang pada awalnya ditujukan untuk mendekati kaum aristokrat atau penguasa dengan imingiming hadiah dalam bentuk silsilah melalui proses perkawinan. Hal ini dilakukan dalam rangka menduduki wilayah tertentu Safira dan Ali Haidar (2014: 235-236).

${ }^{16}$ Syarîf adalah gelar untuk anak laki-laki bagi mereka yang berasal dari keturunan Ḥasān, putra dari Fātimah istri Alī bin Abī Țālib, sedangkan untuk perempuan digunakan syarīfah. Adapun mereka yang berasal dari keturunan Ḥusain menggunakan gelar sayyid untuk anak laki-laki dan sayyidah untuk anak perempuan, tetapi selanjutnya mereka tidak dibeda-bedakan dan dijadikan satu dalam golongan sayyid.

${ }^{17}$ Rizkiati (2012) mengemukakan beberapa alasan komunitas Arab di kota Palembang mempertahankan perkawinan endogami: (a) adanya sistem kekerabatan yang menjaga garis keturunan (nasab); (b) sistem perkawinan yang menjadi suatu kebiasaan yang telah dijalankan dari dahulu sampai sekarang; (c) sebagai identitas dirinya sebagai keturunan Arab; (d) sistem kepercayaan sejak zaman nenek moyang yang mengharuskan mereka kawin secara endogami dan melarang keras mereka untuk melakukan perkawinan eksogami; (e) dalam rangka menjaga keamanan harta dan rahasia keluarga.
} 
Dapat dilihat dari tabel 2 bahwa terdapat 92 jumlah perkawinan (atau 77\%) dari perkawinan masyarakat keturunan Arab yang melakukan perkawinan endogami dengan etnis yang sama. Artinya, masyarakat keturunan Arab sangat menjaga keturunannya, dalam arti lebih condong pada perkawinan sesama keturunan Arab.

Apabila dikaitkan dengan keberlangsungan sebuah bahasa, perkawinan endogami merupakan perkawinan yang mampu memberikan input yang lebih baik terhadap kompetensi bahasa si anak. Hal ini disebabkan karena dalam perkawinan endogami, yang dilakukan dengan satu etnis yang sama, mengindikasikan terjadi pemakaian bahasa yang sama dalam sebuah komunikasi keluarga. Dalam usaha pewarisan bahasa, hal ini merupakan suatu hal yang positif karena perkawinan sesama etnis akan menimbulkan komunitas bahasa monolingual di lingkungan keluarga (bandingkan dengan perkawinan silang antaretnis, yang menurut Thomasson (2001) merupakan salah satu penyebab terjadinya dwibahasawan/multibahasawan). Perkawinan silang akibat dari sistem perkawinan eksogami yang kemudian diikuti oleh situasi kontak bahasa yang intes (kuat) mengarah pada fenomena campur kode dan alih kode, yang cepat atau lambat mengakibatkan pergeseran bahasa. Ini ditegaskan pula oleh Abadi (2007: 152) bahwa perkawinan silang yang merupakan sesuatu yang lumrah terjadi pada komunitas dari berbagai etnis/ras ini membawa implikasi yang begitu jauh ke dalam berbagai ranah kehidupan dan budayanya. Paling tidak beberapa ranah kehidupan yang meliputi arsitektur, makanan, bahasa, pergaulan sehari-hari, kesenian, alat-alat pertukangan, kepercayaan, dan bahkan industri perkapalan tradisional terpengaruh oleh perkawinan silang.

Intinya, dalam perkawinan beda etnis, anak-anak hasil perkawinan kedua individu tersebut akan tumbuh dengan bahasa dan budaya yang berbeda. Bahasa yang digunakan dalam pasangan perkawinan beda etnis, khususnya bahasa yang digunakan oleh anak-anak, dipengaruhi oleh bahasa orang tua mereka.

\subsection{Tradisi perdagangan}

Sejak periode masuknya Islam ke Nusantara, keturunan Arab memiliki andil besar dalam perdagangan Nusantara. Untuk dapat memasuki wilayah Nusantara yang berada langsung di bawah kekuasaan Belanda, mereka datang layaknya pedagang keliling yang membawa barang-barang seperti obat-obatan, sari mawar, permata, tasbih, jimat, air zam-zam (van den Berg, 2010: 43). Bahkan, hingga saat ini umumnya sebagian besar dari mereka pun masih berprofesi sebagai pedagang (Kinasih, 2013; Safira dan Ali Haidar: 2014). Masyarakat keturunan Arab banyak bergerak dalam bidang perdagangan dan swasta terutama menghasilkan produk tekstil dan wangi-wangian (Kinasih, 2013: 41). Selebihnya terbagi dalam berbagai perdagangan lain ${ }^{18}$. Hal ini pun berimbas pada ekspresi leksikon yang berkaitan dengan perdagangan (ekonomi). Sebagaimana disampaikan oleh Husin (2009: 55), bahwa kemudian istilah-istilah atau jargon perdagangan yang muncul pada bahasa Arab-Banjar misalnya: šugūl dari makna 'kesibukan' menjadi 'pekerjaan'; raxīṣ 'murah' goli 'mahal'; den 'hutang'; nagit 'bayar kontan'. Beberapa kosa kata yang berkaitan dengan istilah perdagangan lain seperti yang tercantum pada tabel 3 berikut.

\footnotetext{
${ }^{18}$ Kebanyakan masyarakat keturunan Arab yang tinggal di Kelurahan Klego, Pekalongan memiliki usaha yang cukup besar seperti usaha rumahan pembuatan kain tenun, kopiah, kain ihram, dan lain-lain. Beberapa yang lain berjualan tasbih, kaligrafi, dan peralatan berbau Arab lainnya (Kinasih, 2013: 39;42).
} 
Tabel 3. Perbandingan Kosakata Bahasa Arab-Pekalongan dan Arab Standar

\begin{tabular}{|c|c|c|}
\hline Arab-Pekalongan & Arab Standar & Makna \\
\hline šaybān & wālidāni & 'orang tua' \\
\hline mendreng & al-murābiy & 'rentenir' \\
\hline nihāyah & ?āxiru Өaman & 'harga mati' \\
\hline abū raxīss & raxișjiddan & 'sangat murah' \\
\hline ?ifritt & baxil & 'pelit' \\
\hline ?ahlu dayn & mudīn & 'tukang utang' \\
\hline
\end{tabular}

Sumber: Azzuhri (2013: 324-326).

Di samping itu, pemberian nama untuk warung ataupun toko milik keturunan Arab di daerah Pasarkliwon, Surakarta juga merupakan gejala yang unik. Mereka memberi nama dengan nama-nama yang identik dengan nuansa kearaban, misalnya:, Ulil Albab, al-Madinah, Abu Nawas, Amira, Hammudy, Djamal, asy-Syifa, Amrila, al-Adeny, Salmin, Marwa, as-Shafa, Shafira. Selain itu, komoditas yang diperdagangkan juga berhubungan dengan Islam dan Arab seperti: biro perjalanan haji dan umrah; perlengkapan serta oleh-oleh haji dan umrah (ihram, kurma, pakaian, kacang-kacangan, zam-zam) yang dimaknai membutuhkan kontak dengan negara Arab (khususnya Arab Saudi).

\section{Simpulan}

Kedatangan orang Arab secara massal terjadi pada abad ke-18, namun banyak ahli berkeyakinan bahwa orang Arab sudah berdatangan jauh sebelum proses islamisasi di Indonesia pada abad ke-15 dan ke16. Kedatangan imigran Arab ini pada umumnya kaum lelaki tanpa membawa istri. Setelah menetap, pendatang Arab ini mengutamakan menikah dengan perempuan Arab dari keluarga Arab yang telah menetap sebelumnya dan banyak pula melakukan perkawinan dengan pribumi. Adapun perubahan bahasa yang terjadi pada bahasa Arab-Nusantara adalah bukti dari sebuah adaptasi bahasa terhadap lingkungannya (terutama bahasa-bahasa sekitar). Ini berarti kondisi lingkungan sekitar memberikan kontribusi yang nyata terhadap kelangsungan hidup sebuah bahasa.

Apa yang telah saya sampaikan sebelumnya sekiranya dapat menunjukkan bukti bahwa ekologi bahasa memiliki fungsi pokok dalam rangka menjaga keberlangsungan keberagaman bahasa; dan apabila ekologinya terganggu, maka akan berpengaruh pula terhadap bahasa tersebut.

\section{Saran}

Saya berharap, bahwa para keturunan Arab tidak lagi dipandang sebagai warga asing. Mengingat kontribusinya terhadap islamisasi di Nusantara hingga menjadikan negeri ini sebagai penduduk muslim terbanyak di seluruh dunia, perjuangan kemerdekaan RI dengan munculnya Partai Arab Indonesia (PAI), hingga usaha mereka memajukan bangsa ini $^{19}$. Nilai-nilai positif dalam peri kehidupan mereka sudah selayaknya dapat diadaptasi lebih baik lagi. Dalam konteks ilmiah, seharusnya penelitian ataupun kajian terhadap para keturunan Arab dapat lebih diperbanyak karena selama ini tulisan-tulisan mengenai mereka masih didominasi oleh keturunan Arab.

\footnotetext{
${ }^{19}$ sebut saja Rifat Sungkar, Habib Riziq Syihab, Haddad Alwi, Anies Baswedan, Malik Bawazier, Jimly Asshiddiqie, Najwa Shihab
} 


\section{Daftar Pustaka}

Abadi, M. Masyhur. 2007. "Cross Marriage: Sebuah Model Pembauran Budaya Antar Komunitas Cina, Arab, India, Jawa dan Madura di Sumenep Kota” dalam jurnal KARSA, Vol. XII No. 2 Oktober 2007. hlm. 149-16o.

Ansaldo, Umberto. 2009. Contact Languages: Ecology and Evolution in Asia. Cambridge: Cambridge University Press.

Aribowo, Eric Kunto. 2014. "Bahasa Hibrida: Bukti Harmoni Akulturasi Budaya Arab-Nusantara" makalah dipresentasikan pada Seminar Tahunan Linguistik (SETALI) di Universitas Pendidikan Indonesia, 14 Agustus 2014.

Azzuhri, Muhandis. 2011. "Konvensi Bahasa dan Harmoni Sosial Telaah Linguistik dalam Percakapan Campur Bahasa Arab-Jawa dan Kontribusinya terhadap Harmonisasi Sosial di Masyarakat Kampung Arab Klego - Pekalongan" dalam Jurnal Penelitian Vol. 8, No. 1, Mei 2011. hlm. 37—56.

Azzhuri, Muhandis. 2013. "Relasi Bahasa Arab dengan Strata Sosial Masyarakat dan Implikasinya Terhadap Kehidupan Sosial, Ekonomi, Politik dan Agama: Kajian Sosiolinguistik pada Masyarakat Tutur Arab Keturunan di Kelurahan Kauman Pekalongan Timur" dalam Jurnal Penelitian Vol. 10, No. 2, November 2013. hlm. 313-335.

Fachruddin, Chalida. 2005. "Orang Arab di Kota Medan" dalam Jurnal Antropologi Sosial Budaya ETNOVISI. Vol. 1, No.3, Desember 2005. hlm. 130-135.

Fauziah, Jiah. 2006. "Unsur-Unsur Bahasa Arab dalam Komunikasi Masyarakat Keturunan Arab Surakarta: Sebuah Kajian Pemertahanan dan Pergeseran Bahasa Etnis Migran di Indonesia”. Tesis. Yogyakarta: Universitas Gadjah Mada.

Fuad, Akhmad Dzukaul. 2008. "Bahasa Arab dalam Komunitas Kampung Arab Pamekasan: Sebuah Tinjauan Sosiolinguistik". Tesis. Yogyakarta: Universitas Gadjah Mada.

Husin, Asifudin Ahmad. 20og. "Pemakaian Bahasa Arab oleh Masyarakat Arab di Martapura Kabupaten Banjar Kalimantan Selatan". Disertasi. Yogyakarta: Universitas Gadjah Mada.

Jacobsen, Frode F. 2009. Hadrami Arabs in Present-day Indonesia: An Indonesia-Oriented Group with an Arab Signature. New York: Routledge.

Kinasih, Dian. 2013. "Interaksi Masyarakat Keturunan Arab dengan Masyarakat Setempat di Pekalongan" dalam jurnal Komunitas 5 (1) (2013). hlm. 38-52.

Kridalaksana, Harimurti. 2008. Kamus Linguistik. Jakarta: Gramedia Pustaka Utama.

Mobini-Kesheh, Natalie. 1996. "The Arab Periodicals of the Netherlands East Indies, 1914-1942" dalam Bijdragen tot de Taal-, Land- en Volkenkunde, Deel 152, 2de Afl. (1996), hlm. 236-256 (online) diunduh dari http://www.jstor.org/stable/27864744 diakses 30/o3/2014 19:43.

Mühlhäusler, Peter. 1996. Linguistic Ecology: Language Change and Linguistic Imperialism in The Pacific Region. London and New York: Routledge.

Ricklefs, M.C. 1988. Sejarah Indonesia Modern 1200-2004. Jakarta: Serambi.

Rizkiati, Kurnia. 2013. "Perkawinan Endogami pada Masyarakat Keturunan Arab: Studi di kampung Arab Al-Munawar Kelurahan 13 Ulu Kecamatan Seberang Ulu II Kota Palembang". Skripsi. Palembang: Universitas Sriwijaya.

Safira dan Ali Haidar 2014. "Perkembangan Komunitas Pedagang Arab di Surabaya Tahun 1870-1928" dalam AVATARA, e-Journal Pendidikan Sejarah Volume 2, No. 1, Maret 2014. Hlmn. 232-242.

al-Sharkawi, Muhammad. 2010. The Ecology of Arabic: A Study of Arabicization. Leiden/Boston: Brill. 
Sholihatin, Anis. 2008. "Pemilihan Kode pada Masyarakat Keturunan Arab di Noyontaan, Kota Pekalongan: Kajian Sosiolinguistik". Tesis. Semarang: Universitas Diponegoro.

Thomason, Sarah G. 2001. Language Contact: An Introduction. Edinburg: Edinburg University Press. 